\title{
Convalescent Plasma: The Relay Baton in the Race for Coronavirus Disease 2019 Treatment
}

\section{OPEN ACCESS}

Edited by:

Cornelis Joseph Melief,

Leiden University, Netherlands

Reviewed by:

Jing Yuan,

Children's Hospital of Capital Institute

of Pediatrics, China

Vidya Avinash Arankalle,

National Institute of Virology

(ICMR), India

*Correspondence:

Jean-Pierre Routy

jean-pierre.routy@mcgill.ca

Yaokai Chen

yaokaichen@hotmail.com

tThese authors have contributed equally to this work

Specialty section:

This article was submitted to Vaccines and Molecular Therapeutics,

a section of the journal

Frontiers in Immunology

Received: 19 June 2020 Accepted: 01 September 2020 Published: 23 September 2020

Citation:

Ouyang J, Isnard S, Lin J, Fombuena B, Peng $X$, Routy J-P and Chen Y (2020) Convalescent Plasma:

The Relay Baton in the Race for Coronavirus Disease 2019 Treatment.

Front. Immunol. 11:570063.

doi: 10.3389/fimmu.2020.570063

\begin{abstract}
Jing Ouyang ${ }^{1,2,3 \dagger}$, Stéphane Isnard ${ }^{1,2 \dagger}$, John Lin ${ }^{1,2 \dagger}$, Brandon Fombuena ${ }^{1,2,4}$, Xiaorong Peng ${ }^{1,2,5}$, Jean-Pierre Routy ${ }^{1,2,6 *}$ and Yaokai Chen ${ }^{3 *}$
\end{abstract}

${ }^{1}$ Infectious Diseases and Immunity in Global Health Program, Research Institute, McGill University Health Centre, Montréal, QC, Canada, ${ }^{2}$ Chronic Viral IIIness Service, McGill University Health Centre, Montréal, QC, Canada, ${ }^{3}$ Chongqing Public Health Medical Center, Chongqing, China, ${ }^{4}$ Department of Microbiology and Immunology, McGill University, Montréal, QC, Canada, ${ }^{5}$ State Key Laboratory for Diagnosis and Treatment of Infectious Diseases, National Clinical Research Center for Infectious Diseases, Collaborative Innovation Center for Diagnosis and Treatment of Infectious Diseases, College of Medicine, The First Affiliated Hospital, Zhejiang University, Hangzhou, China, ${ }^{6}$ Division of Hematology, McGill University Health Centre, Montréal, QC, Canada

Coronavirus disease 2019 (COVID-19) is a pandemic caused by the severe acute respiratory syndrome coronavirus-2 (SARS-CoV-2). Most infected people have mild or moderate symptoms and recover without the need for extensive treatment. However, for seriously ill patients, no specific treatments are currently available. Convalescent plasma therapy (CPT), a passive immunotherapy, involves infusing plasma from recovered people into actively infected people, and is thought to be a specific intervention to improve outcome in patients with severe COVID-19. The presumed mechanism involves neutralizing antibodies and antibody dependent cytotoxicity/phagocytosis. Previous CPT trials showed an effect in SARS and pilot studies suggest CPT is an effective and safe strategy for seriously ill COVID-19 patients. CPT is currently being tested in large randomized clinical trials. Herein, we critically review the mechanism, applications and the challenges for CPT in the treatment of severe COVID-19, paving the way toward vaccine and immunotherapy development.

Keywords: coronavirus disease 2019, severe acute respiratory syndrome coronavirus-2, convalescent plasma therapy, immunotherapy, antibody

\section{INTRODUCTION}

Since the first case reported in December 2019, the coronavirus disease 2019 (COVID-19), caused by the severe acute respiratory syndrome coronavirus-2 (SARS-CoV-2), has been declared as a pandemic (1). In a review by the WHO-China Joint Mission of 55,924 laboratory-confirmed cases in China, $80 \%$ of laboratory-confirmed patients with SARS-CoV-2 had mild disease and recovered, $13.8 \%$ had severe disease and $6.1 \%$ were critical (2). According to the WHO guidelines, supportive therapies are recommended to treat COVID-19 symptoms as specific treatments or vaccines for COVID-19 are currently unavailable, while many clinical trials are ongoing (3-10). Therefore, it is urgent to find effective treatment strategies for severe COVID-19.

Convalescent plasma therapy (CPT), a passive immunotherapy, involves infusing patients with antibody-rich plasma from people who have recovered from the same infection. As such, CPT has garnered attention in the treatment of severe COVID-19 as it immediately provides 
specific antibodies to control infection. Use of CPT can be traced back to the Nineteen century, when specific antibodies were sought from the serum of inoculated animals against diphtheria and tetanus (11). Since the 1900s, CPT has been used in the treatment of the Spanish flu, measles, arenaviruses, bunyaviruses, HIV, and coronaviruses (12-18). In 2014, WHO guidelines recommended convalescent plasma collected from patients recovered from Ebola disease for transfusion as an empirical treatment during outbreaks in Africa (19). Mair-Jenkins et al. (17) in 2015 further identified 32 studies of SARS-CoV infection and severe influenza revealing consistent evidences of a reduction in mortality, especially when convalescent plasma is administered early after symptom onset, compared with placebo or no therapy. Based on these study findings, the National Health Commission of China issued a Clinical Treatment Plan of Convalescent Plasma for COVID-19 in March 2020 (20). In April 2020, the US Food and Drug Administration in USA issued guidance for the administration and study of investigational convalescent plasma collected from individuals who have recovered from COVID-19 (21). Subsequently, several clinical trials on convalescent plasma for COVID-19 were initiated.

Herein, we critically review the potential for CPT to treat COVID-19, paving the way toward specific approaches with vaccine and immunotherapy development.

\section{ANTIGEN-SPECIFIC ANTIBODY PRODUCTION AND VIRAL REPLICATION INHIBITION}

COVID-19 recovery and protection appears to be correlated with the development of anti-SARS-CoV-2 antibodies (22). As such, transfer of plasma antibodies from recovered patients could alleviate symptoms in severe cases in pilot studies. Schematic mechanism is shown in Figure 1.

Upon infection, viral antigens are disseminated to secondary lymphoid organs by antigen presenting cells and lymph flow. The antibody production process starts in germinal centers (GC) of lymph nodes that are highly organized: in the light zone, $B$ cells encounter antigens, and follicular $\mathrm{T}$ cells $\left(\mathrm{T}_{\mathrm{FH}}\right)$ induce proliferation and favor survival of the antigen specific cells. In the dark zone, antigen-specific B cells start the antibody hypermutation and class switching processes, notably from immunoglobulin (Ig) M to IgG, in response to a context-specific microenvironment. Hypermutations allow the generation of new B-cells producing variations of antigen specific Ig. After migration back to the light zone, these newly generated Bcells will encounter $\mathrm{T}_{\mathrm{FH}}$ that will favor another round of hypermutation leading to a higher affinity. These processes are further aided by T-cell help in the form of cytokines IL-4 and IL-21, and surface activation of CD40. Only B-cells with the highest affinity for the antigen will continue to divide and differentiate into antibody-producing cells (long-lived memory B cells), among which some will become plasmocytes, that will migrate into the bone marrow to allow long-term production of antibodies (23-25).

Different antibodies would induce various responses with specific functional outcome. Neutralizing antibodies with high affinity can recognize specific viral epitopes and block viral entry, fusion or egress (26). In the case of SARS-CoV, neutralizing antibodies can be raised directly against several SARS-CoV proteins, mainly targeting the spike protein which is involved in receptor recognition, virus attachment and cellular entry through angiotensin-converting enzyme 2 (ACE2) of the host (27-29). More recently, Chen et al. (30) showed that human monoclonal antibodies block the binding of SARS-CoV-2 spike protein to ACE2 receptor. Wu et al. (31) also reported that four monoclonal antibodies isolated from a COVID19 convalescent patient displayed neutralization abilities by preventing binding of virus S-protein receptor binding domain (RBD) to ACE2.

Virus specific non-neutralizing antibodies may also influence outcome. All antibodies consist of an antigen-binding fragment (Fab) which binds to antigens, and a crystallizable fragment $(\mathrm{Fc})$ that binds to cellular surface receptors and proteins from the complement system. The interaction with Fc-receptors can lead to virus-infected cell lysis through a variety of immune effector mechanisms, including antibody-dependent cellular cytotoxicity (ADCC) and antibody-dependent cellular phagocytosis (ADCP) (32). ADCC is a mechanism of cell-mediated immune defense whereby an effector cell of the immune system actively lyses a target cell, whose membrane-surface antigens have been bound by specific antibodies (33). ADCC classically involves natural killer (NK) or T- cells that interact with antigen-bound IgG and lyse the targeted cell $(34,35)$. ADCP is the uptake of virusantibody complexes or antibody-coated virus-infected cells by phagocytic cells such as macrophages or neutrophils (32). In addition, antigen-bound antibodies may activate the complement system inducing complement-dependent cytotoxicity (CDC) (36). Thus, ADCC, ADCP and CDC may exert a broad range of immunomodulatory functions and contribute to the elimination of the virus.

Once a person recovers from a viral infection, antibodies will persist in blood to fight the same virus upon reinfection. SARS-CoV-specific antibodies were detectable about 2 weeks after infection, reaching a peak 60 days after and remaining elevated up to 180 days after (37). Concerningly, antibodies may not persist long-term in SARS patients, as virus-specific IgG titers peaked after 4 months and markedly decreased after one-year post-infection (38). Cao et al. (39) reported that SARS-CoV specific neutralizing antibodies declined gradually 4 months after infection, reaching undetectable levels in $16 \%$ patients at month 36. In case of SARS-CoV-2, Long et al. (40) reported that all 285 patients with COVID-19 tested positive for antiviral immunoglobulin-G (IgG) within 19 days after symptom onset. Both IgG and IgM titers plateaued within 6 days after seroconversion. Wu et al. (41) reported that $70 \%$ of 175 COVID19 recovered patients on the day of discharge generated moderate to high levels of SARS-CoV-2 specific neutralizing antibodies in their plasma. COVID-19 patients generated SARS-CoV-2specific neutralizing antibodies and spike-binding antibodies concurrently from day 10 to 15 after infection and remained stable. There is no obvious difference between the day of discharge and the subsequent visit in 2 weeks, indicating that SARS-CoV-2 specific-antibody levels are stable in the short term in convalescent donors. Chen et al. (30) successfully 


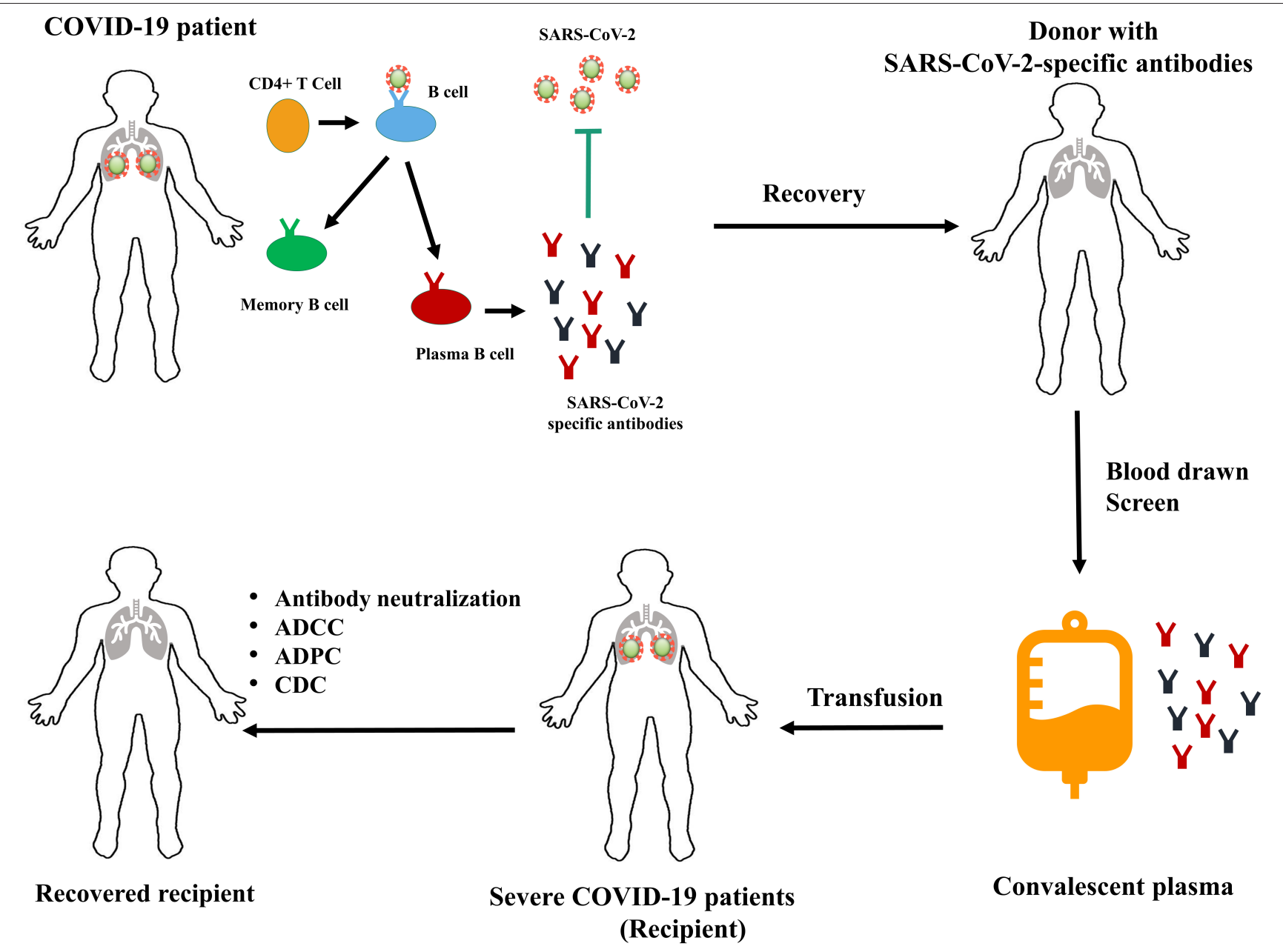

FIGURE 1 | Schematic mechanism of convalescent plasma therapy for COVID-19. ADCC, antibody-dependent cellular cytotoxicity; ADCP, antibody-dependent cellular phagocytosis; CDC, complement-dependent cytotoxicity.

cloned two human blocking monoclonal antibodies using SARSCoV-2 RBD-specific memory $B$ cells isolated from recovered COVID-19 patients, indicating that antibodies can bind to the virus and prevent viral entry. Longer follow up studies are needed to decipher the dynamics of SARS-CoV-2-specific antibody production.

Following identification of those with high antibody titers and those with neutralizing function, convalescent plasma containing SARS-CoV-2-specific antibodies can be transfused into severely ill patients with COVID-19. These antibodies would recognize the virus and provide immediate antiviral effects. Animal models such as rhesus macaques can be used to further study the mechanism of these antibodies, as well as help determine plasma dose, treatment duration, efficacy and safety of CPT (42-44).

However, some studies suggest that severe cases have higher anti-SARS-CoV-2 IgG titers than non-severe cases (40), and antibodies might worsen disease outcome (26). In other SARS infections, high levels of anti-Spike protein promote proinflammatory responses of macrophages while decreasing their tissue repairability (45). As such, carefully designed clinical trials are needed to assess CPT influence on COVID-19 outcome.

\section{APPLICATION IN COVID-19 INFECTION}

Six studies, including 130 critically or severe ill patients with COVID-19 from China or Korea, were reported (Table 1). Pilot studies have shown potential protective effects of CPT in seriously ill patients (46-50). The clinical outcomes of all these patients have improved and they became negative for SARS-CoV2 by PCR within 2-26 days after the transfusion of screened convalescent plasma. Additionally, no severe adverse effects were observed. However, these studies were uncontrolled case series without randomization nor control groups. As such, the clinical benefit of this intervention or whether patients might have spontaneously recovered without therapy is difficult to elucidate. In addition, aside from convalescent plasma, use of other antiviral and supportive therapies may induce bias and confound the direct contribution of convalescent plasma. Recently, in a randomized controlled trial (RCT), Li et al. (51) reported that CPT induced a significant clinical improvement within 28 days and a higher rate of negative PCR conversion in severe patients compared to a control group receiving standard treatment, but showed no significant effects in life-threatened patients. 
TABLE 1 | Reports of convalescent plasma in patients with COVID-19

\begin{tabular}{|c|c|c|c|c|c|c|}
\hline References & Shen et al. (46) & Zhang et al. (47) & Duan et al. (48) & Ahn et al. (49) & Ye et al. (50) & Li et al. (51) \\
\hline Country & China & China & China & Korea & China & China \\
\hline Design & Uncontrolled case series & Uncontrolled case series & Uncontrolled case series & Uncontrolled case series & Uncontrolled case series & $\mathrm{RCT}$ \\
\hline Clinical classification & Critically ill patients & Critically ill patients & Severe patients & Severe patients & Critically ill patients & $\begin{array}{l}\text { Severe or life-threatening } \\
\text { patients }\end{array}$ \\
\hline $\begin{array}{l}\text { Total number of } \\
\text { participant } \\
\text { (Male;female) }\end{array}$ & $5(3,2)$ & $4(2,2)$ & $10(6,4)$ & $2(1,1)$ & $6(3,3)$ & $\begin{array}{l}\text { CPT group:52 }(27,25) \\
\text { Control group: } 51(33,18)\end{array}$ \\
\hline Age, year & $36-65$ & $31-73$ & $34-78$ & $67-71$ & $28-75$ & $\begin{array}{l}\text { Median (IQR) } \\
\text { CPT group } 70 \text { (62-80); } \\
\text { Control group: } 69 \text { (63-76) }\end{array}$ \\
\hline Plasma volume (mL) & 400 & $200-2,400$ & 200 & 500 & $200-600$ & 4 to $13 \mathrm{~mL} / \mathrm{kg}$ \\
\hline Antibody titer & $\begin{array}{l}\text { SARS-CoV-2-specific } \\
\text { antibody (lgG) binding titer } \\
>1: 1,000 \text { and } \\
\text { neutralization titer }>40\end{array}$ & Not determine & $\begin{array}{l}\text { Neutralizing antibody titers } \\
\text { above } 1: 640\end{array}$ & $\begin{array}{l}\text { Optical density ratio for } \\
\text { SARS-CoV-2-specific } \\
\text { antibody lgG }>0.5 \\
\text { (cut-off value } 0.22 \text { ). }\end{array}$ & Not mention & $\begin{array}{l}\text { S-RBD-specific lgG titer } \\
\text { of at least } 1: 640\end{array}$ \\
\hline $\begin{array}{l}\text { Other antiviral } \\
\text { treatment }\end{array}$ & $2-3$ antiviral agents & $2-5$ antiviral agents & $1-3$ antiviral agents & $\begin{array}{l}\text { Lopinavir/ritonavir and } \\
\text { hydroxychloroquine }\end{array}$ & Arbidol & $\begin{array}{l}\text { CPT group: CPT+ } \\
\text { Standard treatment in } \\
\text { China; Control group: } \\
\text { Standard treatment in } \\
\text { China }\end{array}$ \\
\hline Efficacy & $\begin{array}{l}\text { (1) Body temperature } \\
\text { normalized within } 3 \text { days } \\
\text { in } 4 \text { of } 5 \text { patients. (2) Viral } \\
\text { loads became negative } \\
\text { within } 12 \text { days after } \\
\text { the transfusion. }\end{array}$ & $\begin{array}{l}\text { (1) Time from the } \\
\text { transfusion to negative } \\
\text { RT-PCR test results } \\
\text { ranged from } 3 \text { to } 22 \text { days. } \\
\text { (2) All the four patients } \\
\text { recovered }\end{array}$ & $\begin{array}{l}\text { (1) Clinical symptoms } \\
\text { were } \\
\text { significantly improved. (2) } \\
\text { The viral load was } \\
\text { undetectable after } \\
\text { transfusion in all patients } \\
\text { who had previous viremia } \\
\text { with 2-6 days. }\end{array}$ & $\begin{array}{l}\text { (1) Clinical symptoms } \\
\text { were significantly } \\
\text { improved. } \\
\text { (2) SARS-CoV-2 was } \\
\text { negative after } 20 \text { or } 26 \\
\text { days. }\end{array}$ & $\begin{array}{l}\text { (1) Clinical symptoms } \\
\text { were } \\
\text { significantly improved. (2) } \\
\text { SARS-CoV-2 was } \\
\text { negative after } 8-12 \text { days. }\end{array}$ & $\begin{array}{l}\text { (1) For the clinical } \\
\text { improvement within } 28 \\
\text { days, CPT is significantly } \\
\text { better than control in } \\
\text { severe patient, but } \\
\text { comparative in } \\
\text { life-threatening patients. } \\
\text { (2) No significant } \\
\text { difference in 28-day } \\
\text { mortality or time to } \\
\text { discharge. } \\
\text { (3) Significantly higher } \\
\text { negative conversion rate } \\
\text { of viral PCR in CPT group }\end{array}$ \\
\hline Safety & Not reported & $\begin{array}{l}\text { No associated serious } \\
\text { adverse reactions }\end{array}$ & $\begin{array}{l}\text { No severe adverse effects } \\
\text { were observed. }\end{array}$ & $\begin{array}{l}\text { No adverse reactions } \\
\text { were observed. }\end{array}$ & $\begin{array}{l}\text { No obvious adverse effect } \\
\text { observed }\end{array}$ & $\begin{array}{l}\text { Two patients in the CPT } \\
\text { group experienced } \\
\text { adverse events }\end{array}$ \\
\hline
\end{tabular}

$C P T$, Convalescent plasma therapy; $R C T$, randomized controlled trial; RBD: receptor binding domain. 
TABLE 2 | Ongoing clinical trials using convalescent plasma as a treatment for COVID-19.

\begin{tabular}{|c|c|c|c|c|}
\hline $\begin{array}{l}\text { Clinical trial } \\
\text { number }\end{array}$ & Aim & $\begin{array}{l}\text { Number of } \\
\text { participants }\end{array}$ & Intervention & Country \\
\hline NCT04292340 & Treatment & 15 & Convalescent plasma & China \\
\hline NCT04323800 & Prophylaxis & 150 & $\begin{array}{l}\text { Randomized groups } \\
\text { ARM I: Anti-SARS-CoV-2 plasma } \\
\text { ARM II: SARS-CoV-2 non-immune plasma }\end{array}$ & United States \\
\hline NCT04340050 & Treatment & 10 & Anti-SARS-CoV-2 convalescent plasma & United States \\
\hline NCT04332835 & Treatment & 80 & $\begin{array}{l}\text { Randomized groups: } \\
\text { ARM I: Anti-SARS-CoV-2 } \\
\text { plasma+Azithromycin + Hydroxychloroquine } \\
\text { ARM II: Azithromycin + Hydroxychloroquine }\end{array}$ & Colombia \\
\hline NCT04327349 & Treatment & 30 & Convalescent plasma & Iran \\
\hline NCT04348656 & Treatment & 1,200 & $\begin{array}{l}\text { ARM I: Anti-SARS-CoV-2 plasma } \\
\text { ARM II: standard of care }\end{array}$ & Canada \\
\hline
\end{tabular}

These observations justify the need to assess efficacy and safety of CPT in well-designed clinical trials such as the ongoing studies proposed by investigators from Canada, China, Colombia, Iran, Italy and USA, presented in Table 2 . These trials include observational case series and randomized controlled trials, with the size ranging from 10 to 1,200 individuals. For example, the CONvalescent Plasma for Hospitalized Adults With COVID-19 Respiratory Illness (CONCOR-1) (NCT04348656) will recruit 1,200 participants in a randomized open label trial. Johns Hopkins University are currently sponsoring a randomized, blinded phase 2 study (NCT04323800), which plans to include 150 participants to compare the efficacy and safety of SARS-CoV-2 convalescent plasma vs. control (SARS-CoV-2 non-immune plasma) among adults exposed to COVID-19.

\section{CHALLENGES AND FUTURE DIRECTION}

RCT will allow the assessment of utility, efficacy and safety of CPT in COVID-19 patients. However, due to the diverse presentation of the disease, and taking into account the higher risks of developing severe COVID-19 in people with comorbidities, assessments of utility and safety should be evaluated in regard to participant's clinical characteristics and predispositions. Overall, ensuring the safety and efficacy of CPT remains a priority. At the same time, despite recent preliminary results of convalescent plasma for COVID-19, challenges in reducing risk and implementation in the clinic for patients with COVID-19 remain a concern.

There is a concern of antibody-dependent enhancement of infection (ADE), which occurs when antibodies facilitate viral entry into host cells and enhance viral infection $(52,53)$. ADE has been observed for a variety of viruses, such as flaviviruses, HIV and Ebola viruses (54-58). When patients are infected by one serotype of virus, they produce neutralizing antibodies targeting the same serotype of the virus. However, if they are later infected by a virus with a different serotype, the pre-existing antibodies cannot fully neutralize the virus. Instead, the antibodies first bind to the virus and then bind to the IgG Fc receptors on immune cells and mediate viral entry into these cells (59). The available evidence from the use of convalescent plasma in patients with SARS and MERS (17), suggest this does not happen when using plasma with high viral neutralization titers. Even so, it remains necessary to screen the viral serotype of donor and recipient to reduce risk of ADE. Furthermore, Crowe et al. reported that passively-acquired antibodies suppress humoral but not cellmediated immunity in mice immunized with live attenuated respiratory syncytial virus vaccines (60). Therefore, CPT may attenuate immune responses leaving individuals vulnerable to subsequent re-infection.

Donor selection for convalescent plasma also poses a challenge. At the moment, screening donors for specific highaffinity neutralizing antibodies to SARS-CoV-2 may be difficult as there is no standardized assay for such measurement. However, both the FDA and Canadian Blood Services have cast a wide net for potential donors for convalescent plasma trials across North America. In the case of the FDA, convalescent plasma donors must meet the following criteria: (1) have a positive laboratory test through either a diagnostic nasopharyngeal swab or serological test for SARS-CoV-2 antibodies if the nasopharyngeal swab test was not performed, (2) be recovered from COVID-19 symptoms for a minimum of 14 days, with a negative nasopharyngeal swab test being unnecessary, and (3) have never been pregnant or have been tested negative for antiHLA antibodies since their most recent pregnancy. Donors are recommended to have SARS-CoV-2 neutralizing antibody titers of at least $1: 160$ or 1:80, if titer measurements are available (61). Standardized tests assessing anti-SARS-CoV-2 titers and functions would prove useful in the global assessment of RCT results. Moreover, the influence of antibody titers and their antiviral function on clinical outcome should be tested in future 
clinical trials. In addition to usual appropriate testing for bloodborn pathogens, the Canadian Blood Services and Hema-Quebec have implemented screening criteria for Canada's CONCOR-1 trial (NCT04348656), including being younger than 67 years of age, being confirmed positive through a laboratory test, and being fully recovered and symptom-free for a minimum of 28 days (62). As more data become available on the profiles of convalescent plasma donors, including neutralizing antibody titers, and as the supply of convalescent plasma units expands to cope with demand, the ability to whittle down and identify effective donors will also be refined.

Although US and China have issued guidelines for the implementation of CPT clinically (63), there are still gaps needed to be explored, such as the plasma dose, treatment duration, antibody stability and preservation. Historically, the dosing of convalescent plasma has been highly variable for different viruses. The total dose of the patients from the reported COVID-19 studies also ranges from 200 to $2,400 \mathrm{~mL}(46-49)$. Therefore, the dose-effect and time-effect relationships require further study.

Most clinical trials focus on reactive treatment after the onset of symptoms, although previous experience with CPT against SARS or influenza infections showed most benefits before the onset of symptoms. However, detecting and treating people before the onset of symptoms represent a logistical challenge. Moreover, severe cases appear to have higher levels of anti-SARSCoV-2 IgG, hampering the hypothesis of antibodies preventing COVID-19 severity (40). Hence post-exposure prophylaxis might be a particular situation where CPT might decrease COVID-19 clinical outcome (NCT04323800).

Moreover, beyond the ABO plasma compatibility, CPT can result in transfusion-related lung injury and transfusion-related circulatory fluid overload, especially in the predominantly elderly population of those affected by COVID-19. Close medical and nursing surveillance are needed in hospital setting, limiting the scaling-up of such intervention (64).

\section{CONCLUSION}

COVID-19 is a new global health crisis currently lacking specific treatments or vaccines. CPT has been explored in other infections

\section{REFERENCES}

1. Coronavirus COVID-19 Global Cases by the Center for Systems Science and Engineering at Johns Hopkins: Johns Hopkins University. Available online at: https://coronavirus.jhu.edu/map.html (accessed April 13, 2020)

2. Mission WCJ. Report of the WHO-China Joint Mission on Coronavirus Disease 2019 (COVID-19). Available online at: https://www.who.int/docs/defaultsource/coronaviruse/who-china-joint-mission-on-covid-19-final-report.pdf (accessed April 07, 2020).

3. Cao B, Wang Y, Wen D, Liu W, Wang J, Fan G, et al. A trial of lopinavirritonavir in adults hospitalized with severe covid-19. N Engl J Med. (2020) 382:1787-99. doi: 10.1056/NEJMoa2001282

4. Chen J, Ling Y, Xi X, Liu P, Li F, Li T, et al. Efficacies of lopinavir/ritonavir and abidol in the treatment of novel coronavirus pneumonia (in Chinese). Chin J Infect Dis. (2020) 38:E008-E. doi: 10.3760/cma.j.issn.1000-6680.2020. 02.006 and its efficacy and safety in the treatment of COVID-19 is currently being assessed in several clinical trials, including large RCT.

Determining clinical markers of appropriate timing and dose of CPT is the current priority before implementation in the clinical setting. In the future, the dynamics and mechanism of anti-SARS-CoV-2 specific antibody and antibody-dependent effects need to be studied at the cellular level with specific $\mathrm{T}$ and $\mathrm{B}$ cell responses to drive further innovation in treatment. Overall, collaborative efforts encompassing immunology, hematology, clinical care and pharmacy will optimize and facilitate CPT in the fight against COVID-19, paving the way for targeted therapies and vaccines.

\section{AUTHOR CONTRIBUTIONS}

JO, SI, and JL wrote the first draft of the manuscript. BF and $\mathrm{XP}$ provided critical revision of the manuscript. J-PR and YC conceived and designed the manuscript. All authors approved it for publication.

\section{FUNDING}

Our research is funded by the Fonds de la Recherche Québec-Santé (FRQ-S): Réseau SIDA/Maladies infectieuses and Thérapie cellulaire; the Canadian Institutes of Health Research (CIHR; grants MOP 103230 and PTJ 166049); the Vaccines \& Immunotherapies Core of the CIHR Canadian HIV Trials Network (CTN; CTN PT038); the Canadian Foundation for AIDS Research (CANFAR; grant 02-512); CIHR- funded Canadian HIV Cure Enterprise (CanCURE) Team Grant HB2-164064; and Chongqing Special Research Project for Novel Coronavirus Pneumonia Prevention and Control (cstc2020jscx-fyzx0074).

\section{ACKNOWLEDGMENTS}

We are highly grateful to Angie Massicotte, Josée Girouard, and Cezar Iovi for coordination and assistance. 
9. Magagnoli J, Narendran S, Pereira F, Cummings T, Hardin JW, Sutton SS, et al. Outcomes of hydroxychloroquine usage in United States veterans hospitalized with Covid-19. medRxiv. (2020). doi: 10.1016/j.medj.2020.06.001. [Epub ahead of print].

10. Juurlink DN. Safety considerations with chloroquine, hydroxychloroquine and azithromycin in the management of SARS-CoV-2 infection. CMAJ. (2020) 192:E450-3. doi: 10.1503/cmaj.200528

11. Garraud O, Heshmati F, Pozzetto B, Lefrere F, Girot R, Saillol A, et al. Plasma therapy against infectious pathogens, as of yesterday, today and tomorrow. Transfusion Clinique Biol J Soc francaise Transfusion Sanguine. (2016) 23:3944. doi: 10.1016/j.tracli.2015.12.003

12. Luke TC, Kilbane EM, Jackson JL, Hoffman SL. Meta-analysis: convalescent blood products for Spanish influenza pneumonia: a future H5N1 treatment? Ann Intern Med. (2006) 145:599-609. doi: 10.7326/0003-4819-145-8-200610170-00139

13. Zingher A, Mortimer P. Convalescent whole blood, plasma and serum in the prophylaxis of measles: JAMA, 12 April, 1926; 1180-1187. Rev Med Virol. (2005) 15:407-18. doi: 10.1002/rmv.480

14. Frame JD, Verbrugge GP, Gill RG, Pinneo L. The use of Lassa fever convalescent plasma in Nigeria. Trans R Soc Trop Med Hyg. (1984) 78:319-24. doi: 10.1016/0035-9203(84)90107-X

15. Peters CJ, Reynolds JA, Slone TW, Jones DE, Stephen EL. Prophylaxis of Rift Valley fever with antiviral drugs, immune serum, an interferon inducer, and a macrophage activator. Antiviral Res. (1986) 6:285-97. doi: 10.1016/0166-3542(86)90024-0

16. Morand-Joubert L, Vittecoq D, Roudot-Thoraval F, Mariotti M, Lefrere F, Heshmati F, et al. Virological and immunological data of AIDS patients treated by passive immunotherapy (transfusions of plasma rich in HIV-1 antibodies). Vox Sanguinis. (1997) 73:149-54. doi: 10.1159/000461922

17. Mair-Jenkins J, Saavedra-Campos M, Baillie JK, Cleary P, Khaw FM, Lim WS, et al. The effectiveness of convalescent plasma and hyperimmune immunoglobulin for the treatment of severe acute respiratory infections of viral etiology: a systematic review and exploratory meta-analysis. J Infect Dis. (2015) 211:80-90. doi: 10.1093/infdis/j iu396

18. Marano G, Vaglio S, Pupella S, Facco G, Catalano L, Liumbruno GM, et al. Convalescent plasma: new evidence for an old therapeutic tool? Blood Transfus. (2016) 14:152-7. doi: 10.2450/2015.0131-15

19. Use of convalescent whole blood or plasma collected from patients recovered from Ebola virus disease for transfusion, as an empirical treatment during outbreaks: WHO (2014). Available online at: http://apps.who.int/iris/rest/ bitstreams/604045/retrieve (accessed April 15, 2020).

20. Clinical Treatment Plan of Convalescent Plasma for COVID-19: National Health Commission of China; (2020). Available online at: http://www.gov. cn/zhengce/zhengceku/2020-03/05/content_5487145.htm (accessed April 15, 2020).

21. Recommendations for Investigational COVID-19 Convalescent Plasma: US Food and Drug Administration (2020). Available from: https://www. fda.gov/vaccines-blood-biologics/investigational-new-drug-ind-or-deviceexemption-ide-process-cber/recommendations-investigational-covid-19convalescent-plasma (accessed April 15, 2020).

22. Ni L, Ye F, Cheng M-L, Feng Y, Deng Y-Q, Zhao H, et al. Detection of SARSCoV-2-specific humoral and cellular immunity in COVID-19 convalescent individuals. Immunity. (2020) 52:971-7. doi: 10.1016/j.immuni.2020.0 4.023

23. Crotty S. T follicular helper cell differentiation, function, and roles in disease. Immunity. (2014) 41:529-42. doi: 10.1016/j.immuni.2014.10.004

24. Janice Oh HL, Ken-En Gan S, Bertoletti A, Tan YJ. Understanding the T cell immune response in SARS coronavirus infection. Emerg Microbes Infect. (2012) 1:e23. doi: 10.1038/emi.2012.26

25. Li G, Fan Y, Lai Y, Han T, Li Z, Zhou P, et al. Coronavirus infections and immune responses. J Med Virol. (2020) 92:424-32. doi: 10.1002/jmv.25685

26. Iwasaki A, Yang Y. The potential danger of suboptimal antibody responses in COVID-19. Nat Rev Immunol. (2020) 20:339-41. doi: 10.1038/s41577-020-0321-6

27. Du L, He Y, Zhou Y, Liu S, Zheng BJ, Jiang S. The spike protein of SARS-CoVa target for vaccine and therapeutic development. Nat Rev Microbiol. (2009) 7:226-36. doi: 10.1038/nrmicro2090
28. Lu R, Zhao X, Li J, Niu P, Yang B, Wu H, et al. Genomic characterisation and epidemiology of 2019 novel coronavirus: implications for virus origins and receptor binding. Lancet. (2020) 395:565-74. doi: 10.1016/S0140-6736(20)30251-8

29. Wan Y, Shang J, Graham R, Baric RS, Li F. Receptor recognition by novel coronavirus from Wuhan: an analysis based on decade-long structural studies of SARS. J Virol. (2020) 19:e00127-20. doi: 10.1128/JVI.00127-20

30. Chen X, Li R, Pan Z, Qian C, Yang Y, You R, et al. Human monoclonal antibodies block the binding of SARS-CoV-2 spike protein to angiotensin converting enzyme 2 receptor. Cell Mol Immunol. (2020) 17:647-9. doi: 10.1038/s41423-020-0426-7

31. Wu Y, Wang F, Shen C, Peng W, Li D, Zhao C, et al. A noncompeting pair of human neutralizing antibodies block COVID-19 virus binding to its receptor ACE2. Science. (2020) 368:1274-8. doi: 10.1101/2020.05.01.20077743

32. van Erp EA, Luytjes W, Ferwerda G, van Kasteren PB. Fc-mediated antibody effector functions during respiratory syncytial virus infection and disease. Front Immunol. (2019) 10:548. doi: 10.3389/fimmu.2019.00548

33. Hashimoto G, Wright PF, Karzon DT. Antibody-dependent cell-mediated cytotoxicity against influenza virus-infected cells. J Infect Dis. (1983) 148:78594. doi: 10.1093/infdis/148.5.785

34. Wang W, Erbe AK, Hank JA, Morris ZS, Sondel PM. NK cell-mediated antibody-dependent cellular cytotoxicity in cancer immunotherapy. Front Immunol. (2015) 6:368. doi: 10.3389/fimmu.2015.00368

35. Newton AH, Cardani A, Braciale TJ. The host immune response in respiratory virus infection: balancing virus clearance and immunopathology. Semin Immunopathol. (2016) 38:471-82. doi: 10.1007/s00281-016-0558-0

36. Peschke B, Keller CW, Weber P, Quast I, Lunemann JD. Fc-galactosylation of human immunoglobulin gamma isotypes improves $\mathrm{C} 1 \mathrm{q}$ binding and enhances complement-dependent cytotoxicity. Front Immunol. (2017) 8:646. doi: 10.3389/fimmu.2017.00646

37. Mo HY, Xu J, Ren XL, Zeng GQ, Tan YX, Chen RC, et al. Evaluation by indirect immunofluorescent assay and enzyme linked immunosorbent assay of the dynamic changes of serum antibody responses against severe acute respiratory syndrome coronavirus. Chin Med J. (2005) 118:446-50.

38. Channappanavar R, Zhao J, Perlman S. T cell-mediated immune response to respiratory coronaviruses. Immunol Res. (2014) 59:118-28. doi: 10.1007/s12026-014-8534-Z

39. Cao WC, Liu W, Zhang PH, Zhang F, Richardus JH. Disappearance of antibodies to SARS-associated coronavirus after recovery. $N$ Engl J Med. (2007) 357:1162-3. doi: 10.1056/NEJMc070348

40. Long QX, Liu BZ, Deng HJ, Wu GC, Deng K, Chen YK, et al. Antibody responses to SARS-CoV-2 in patients with COVID-19. Nat Med. (2020) 26:845-8. doi: 10.1038/s41591-020-0897-1

41. Wu F, Wang A, Liu M, Wang Q, Chen J, Xia S, et al. Neutralizing antibody responses to SARS-CoV-2 in a COVID-19 recovered patient cohort and their implications. medRxiv [Preprint]. (2020). doi: 10.1101/2020.03.30.20047365

42. Yu P, Qi F, Xu Y, Li F, Liu P, Liu J, et al. Age-related rhesus macaque models of COVID-19. Animal Model Exp Med. (2020) 3:93-7. doi: 10.1002/ame2.12108

43. Deng W, Bao L, Liu J, Xiao C, Liu J, Xue J, et al. Primary exposure to SARS-CoV-2 protects against reinfection in rhesus macaques. Science. (2020) 369:818-23. doi: 10.1126/science.abc5343

44. Elizaldi S, Lakshmanappa YS, Roh J, Schmidt B, Carroll T, Weaver $\mathrm{K}$, et al. SARS-CoV-2 infection induces robust germinal center CD4 T follicular helper cell responses in rhesus macaques. Res Sq. (2020). doi: 10.21203/rs.3.rs-51545/v1. [Epub ahead of print].

45. Liu L, Wei Q, Lin Q, Fang J, Wang H, Kwok H, et al. Antispike IgG causes severe acute lung injury by skewing macrophage responses during acute SARS-CoV infection. JCI Insight. (2019) 4:e123158. doi: 10.1172/jci.insight.123158

46. Shen C, Wang Z, Zhao F, Yang Y, Li J, Yuan J, et al. Treatment of 5 critically ill patients with COVID-19 with convalescent plasma. Jama. (2020) 323:1582-9. doi: 10.1001/jama.2020.4783

47. Zhang B, Liu S, Tan T, Huang W, Dong Y, Chen L, et al. Treatment with convalescent plasma for critically ill patients with SARS-CoV-2 infection. Chest. (2020) 158:e9-13. doi: 10.1016/j.chest.2020.03.039

48. Duan K, Liu B, Li C, Zhang H, Yu T, Qu J, et al. Effectiveness of convalescent plasma therapy in severe COVID-19 patients. Proc Natl Acad Sci USA. (2020) 117:9490-6. doi: 10.1073/pnas.2004168117 
49. Ahn JY, Sohn Y, Lee SH, Cho Y, Hyun JH, Baek YJ, et al. Use of convalescent plasma therapy in two COVID-19 patients with acute respiratory distress syndrome in Korea. J Korean Med Sci. (2020) 35:e149. doi: 10.3346/jkms.2020.35.e149

50. Ye M, Fu D, Ren Y, Wang F, Wang D, Zhang F, et al. Treatment with convalescent plasma for COVID-19 patients in Wuhan, China. J Med Virol. (2020). doi: 10.1002/jmv.25882. [Epub ahead of print].

51. Li L, Zhang W, Hu Y, Tong X, Zheng S, Yang J, et al. Effect of convalescent plasma therapy on time to clinical improvement in patients with severe and life-threatening COVID-19: a randomized clinical trial. Jama. (2020) 324:1-11. doi: 10.1001/jama.2020.10044

52. Tirado SM, Yoon KJ. Antibody-dependent enhancement of virus infection and disease. Viral Immunol. (2003) 16:69-86. doi: 10.1089/088282403763635465

53. Tetro JA. Is COVID-19 receiving ADE from other coronaviruses? Microbes Infect. (2020) 22:72-3. doi: 10.1016/j.micinf.2020.02.006

54. Dejnirattisai W, Jumnainsong A, Onsirisakul N, Fitton P, Vasanawathana S, Limpitikul W, et al. Cross-reacting antibodies enhance dengue virus infection in humans. Science. (2010) 328:745-8. doi: 10.1126/science.1185181

55. Katzelnick LC, Gresh L, Halloran ME, Mercado JC, Kuan G, Gordon A, et al. Antibody-dependent enhancement of severe dengue disease in humans. Science. (2017) 358:929-32. doi: 10.1126/science.aan6836

56. Willey S, Aasa-Chapman MM, O'Farrell S, Pellegrino P, Williams I, Weiss RA, et al. Extensive complement-dependent enhancement of HIV-1 by autologous non-neutralising antibodies at early stages of infection. Retrovirology. (2011) 8:16. doi: 10.1186/1742-4690-8-16

57. Kuzmina NA, Younan P, Gilchuk P, Santos RI, Flyak AI, Ilinykh PA, et al. Antibody-dependent enhancement of ebola virus infection by human antibodies isolated from survivors. Cell Rep. (2018) 24:1802-15 e5. doi: 10.1016/j.celrep.2018.07.035

58. Takada A, Feldmann H, Ksiazek TG, Kawaoka Y. Antibody-dependent enhancement of Ebola virus infection. J Virol. (2003) 77:7539-44. doi: 10.1128/JVI.77.13.7539-7544.2003
59. Wan Y, Shang J, Sun S, Tai W, Chen J, Geng Q, et al. Molecular mechanism for antibody-dependent enhancement of coronavirus entry. J Virol. (2020) 94:e02015-19.. doi: 10.1128/JVI. 02015-19

60. Crowe JE Jr, Firestone CY, Murphy BR. Passively acquired antibodies suppress humoral but not cell-mediated immunity in mice immunized with live attenuated respiratory syncytial virus vaccines. J Immunol. (2001) 167:3910-8. doi: 10.4049/jimmunol.167. 7.3910

61. ADMINISTRATION USFaD. Recommendations for Investigational COVID19 Convalescent Plasma 2020. Available online at: https://www.fda. gov/vaccines-blood-biologics/investigational-new-drug-ind-or-deviceexemption-ide-process-cber/recommendations-investigational-covid-19convalescent-plasma (accessed May 16, 2020).

62. Service CB. COVID-19 and Convalescent Plasma 2020. Available online at: https://blood.ca/en/convalescentplasma (accessed May 16, 2020)

63. WHO. Recommendations for Investigational COVID-19 Convalescent Plasma. Food and Drug Administration (2020).

64. Dzik S. COVID-19 convalescent plasma: now is the time for better science. Transfus Med Rev. (2020) 34:141-4. doi: 10.1016/j.tmrv.2020. 04.002

Conflict of Interest: The authors declare that the research was conducted in the absence of any commercial or financial relationships that could be construed as a potential conflict of interest.

Copyright (C) 2020 Ouyang, Isnard, Lin, Fombuena, Peng, Routy and Chen. This is an open-access article distributed under the terms of the Creative Commons Attribution License (CC BY). The use, distribution or reproduction in other forums is permitted, provided the original author(s) and the copyright owner(s) are credited and that the original publication in this journal is cited, in accordance with accepted academic practice. No use, distribution or reproduction is permitted which does not comply with these terms. 